\title{
Pulmonary tuberculosis with atypical presentation because of unknown previous HIV infection - case report
}

Cristina Călărașu ${ }^{1,2, \dagger}$, Mimi Niţu ${ }^{1,3}$, Mădălina Olteanu ${ }^{4}$, Andreea Loredana Golli5 ${ }^{5}$ Florentina Dumitrescu ${ }^{6,7}$, Mihai Olteanu $^{1,3}$

${ }^{1}$ Victor Babes Clinical Hospital of Infectious Diseases and Pneumophtisiology, Pneumology Department, Craiova, Romania

${ }^{2} P h D$ Student, Department of Medical Specialities, University of Medicine and Pharmacy of Craiova, Craiova, Romania

${ }^{3}$ University of Medicine and Pharmacy of Craiova, Internal Medicine Department, Craiova, Romania

${ }^{4}$ University of Medicine and Pharmacy of Craiova, Dentistry Department, Craiova, Romania

${ }^{5}$ University of Medicine and Pharmacy of Craiova, Public Health Department, Craiova, Romania

${ }^{6}$ Victor Babes Clinical Hospital of Infectious Diseases and Pneumophtisiology, HIV Department, Craiova, Romania

Abstract

${ }^{7}$ University of Medicine and Pharmacy of Craiova, Infectious Diseases Department, Craiova, Romania

English:

Background: People coinfected with tuberculosis (TB) and human immunodeficiency virus (HIV) are 20-37 times more likely to develop active TB disease than non-HIV-infected people. Syndemic interaction between HIV and TB epidemics has made testing for TB a must for HIV-infected people and vice versa. We present the case of a young male diagnosed with HIV infection, due to mandatory HIV testing for all TB cases in Romania.

Case presentation: A 30-year-old man was hospitalized for fever, chills and productive cough not influenced by previous antibiotic home treatment. He was admitted with tachycardia and bilateral presence of coarse crackles in lower pulmonary areas. Chest X-ray suggested bilateral bronchopneumonia; the results from blood tests showed inflammation, leukocytosis and anaemia. Hemocultures were negative. Under wide-spectrum antibiotic treatment, his general condition partially improved, but on the seventh day, chest $X$-ray revealed abscess in the left inferior lobe and the progression of previous lesions. Chest computed tomography revealed multiple large consolidation areas in both lung areas, a $13 \mathrm{~cm}$ diameter abscess and multiple mediastinal adenopathy of 2-4 cm in diameter. Acid fast bacilli smear from sputum was positive. After the diagnosis of pulmonary TB, anti-TB treatment was started; the patient was subsequently diagnosed with HIV infection. He received specific anti-TB treatment, and 3 weeks later, retroviral treatment was initiated. Clinical evolution was favourable and radiological appearance improved. In addition, he did not present any adverse effects of therapy.

Conclusions: HIV testing for all TB cases is a must because HIV-TB coinfection raises important diagnostic and treatment problems.

Keywords

Tuberculosis $\bullet H I V \cdot$ coinfection

\section{Tuberculoza pulmonară cu prezentare atipică datorată infecției HIV nou descoperită: prezentare de caz}

Rezumat

Romanian:

Context: Persoanele co-infectate cu tuberculoză (TB) și HIV (virusul imunodeficienței umane) sunt de 20-37 ori mai predispuse la dezvoltarea TB boală activă decât persoanele neinfectate cu HIV. Interacțiunea sindemică dintre epidemiile de HIV și TB a făcut ca testarea tuberculozei să devină o necesitate pentru persoanele infectate cu HIV și invers. Prezentăm cazul unui bărbat diagnosticat cu infecție HIV, ca urmare a testării obligatorii HIV pentru toate cazurile de TB în România.

Prezentarea cazului: Bărbat de 30 de ani internat pentru febră, frisoane, tuse productivă neinfluențată de tratamentul anterior cu antibiotice. Asociat prezenta tahicardie și raluri bronșice în zonele pulmonare inferioare.

Radiografia toracică sugera bronhopneumonie bilaterală și paraclinic sindrom inflamator, leucocitoză și anemie. Hemoculturile au fost negative.

+Corresponding author: Cristina Călărașu

E-mail: calarasu.cristina@yahoo.com

ə Open Access. @ 2019 Călărașu et al., published by Sciendo

(ख) Br-Nc-ND This work is licensed under the Creative Commons Attribution-NonCommercial-NoDerivs 4.0 License. 
Sub tratament antibiotic nespecific starea generală s-a îmbunătățit parțial, dar radiografia toracică efectuată după 7 zile a identificat abces în lobul inferior stâng și progresia leziunilor descrise anterior. Tomografia computerizată toracică a evidențiat multiple zone de consolidare bilateral, un abces de $13 \mathrm{~cm}$ diametru, adenopatii mediastinale multiple de 2-4 cm. Examenul de spută pentru bacilul Koch a fost pozitiv.

S-a stabilit diagnosticul de TB pulmonară şi s-a instituit tratament anti-TB, ulterior fiind diagnosticat și cu infecție HIV. Pacientul a primit tratament anti-TB specific și, după 3 săptămâni, a fost inițiat tratamentul retroviral. Evoluția clinică a fost favorabilă și aspectul radiologic s-a îmbunătătit. De asemenea, nu a prezentat nici un efect advers al terapiei.

Concluzii: Testarea HIV pentru toate cazurile de TB este o necesitate deoarece coinfecția HIV-TB ridică probleme importante de diagnostic și tratament.

Cuvinte-cheie

Tuberculoza $\cdot H I V \cdot$ coinfecție

\section{Background}

Tuberculosis (TB) is the commonest and the deadliest opportunistic infection in patients living with human immunodeficiency virus (HIV)/AIDS (acquired immune deficiency syndrome). In the last three decades, there has been a progressive increase in the number of cases of TB across the globe due to many factors like: increasing HIV incidence since 1980, low economic status of some nations, migration and emergence of resistant strains of TB bacillus $(1,2)$.

The syndemic interaction between the human immunodeficiency virus (HIV) and TB epidemics is responsible for millions of people infected and millions of people dead as well as for major economic costs around the world. TB-HIV coinfection causes accelerated immune system damage with an increased mortality. Literature proves that of all the opportunistic infections affecting people living with HIV (PLH), TB is the most common affecting more than one-third of them, increasing the risk for mortality $(2,3)$.

World Health Organization (WHO) has declared TB as a global emergency since 1993, and Mycobacterium tuberculosis has the highest mortality of all pathogens. According to WHO data, the risk of developing active TB is about 20-37 times higher among PLH especially in endemic countries compared to a $10 \%$ risk in HIV-negative people. Still, one-quarter of the estimated 2 million HIVrelated deaths worldwide in 2008 were because of TB infections. TB is also the leading cause of death for PLH in low- and middle-income countries (4).

Today, the value of the global incidence (new cases and relapses) of TB in our country is the highest in the European Union and one of the highest in the WHO European Region (fifth place after Kazakhstan, Moldova, Georgia and Kyrgyzstan). The number of new cases and recurrences recorded annually decreased progressively from 30,984 in 2002 to 17,694 in 2011, reaching 12,836 in 2016 (5-7).

The National Program for the Prevention and Control of Tuberculosis (PNCT) in Romania aims to reduce the transmission, morbidity and mortality of TB until it is no longer a national public health problem. In this respect, the PNCT and European Centre for Disease Prevention and Control (ECDC) respecting WHO guidelines regarding TB control developed programs to be implemented between 2015 and 2020 (5-7).

Syndemic interaction between HIV and TB epidemics has made testing for TB a must for HIV-infected people and vice versa, as a form of early prevention and treatment (4-7).

Case presentation: A 30-year-old man, non-smoker, was hospitalized in 2017 for fever, chills and productive cough, symptoms that were not influenced by previous home treatment including antibiotics prescribed by the general practitioner (Clarithromycin $1000 \mathrm{mg} /$ daily for 7 days, associated with lbuprofen when needed).

He was admitted with high fever $\left(40.2^{\circ} \mathrm{C}\right)$ accompanied by intense sweating, tachycardia (heart rate (126 bpm) and bilateral presence of abnormal breath sounds (coarse crackles in lower pulmonary areas). Blood pressure was normal $(110 / 60 \mathrm{mmHg})$, and oxygen saturation was $98 \%$. The rest of the physical examination was normal too.

Chest X-ray at admission evidenced multiple diffuse opacities distributed in the half inferior part of both lung areas, suggestive of bilateral bronchopneumonia (Figure 1).

Results from blood tests evidenced inflammation (erythrocyte sedimentation rate $(E S R)>120 \mathrm{~mm}$ at $1 \mathrm{~h}$ ), leukocytosis (white blood cells $(\mathrm{WBC})=14,000 / \mathrm{mmc})$, anaemia $(\mathrm{Hb}=10.9 \mathrm{~g} / \mathrm{dl})$, aspartate transaminase $(\mathrm{AST})=74 \mathrm{U} / \mathrm{l}$ and alanine transaminase $(A L T)=57 \mathrm{U} / \mathrm{l}$. The other results were within normal limits.

Sputum examination did not identify any pathogen, and hemoculture results were negative.

Under wide-spectrum antibiotic treatment (with ampicillin/ sulbactam $4.5 \mathrm{~g} /$ daily and Levofloxacinum $1000 \mathrm{mg} /$ daily), his general condition partially improved, but he was still presenting nocturnal subfebrile values $\left(37.3^{\circ} \mathrm{C}-37.8^{\circ} \mathrm{C}\right)$ and mild chest pain. Chest X-ray was repeated after 7 days from admission and revealed a big oval cavity of $13 \mathrm{~cm}$ in the left inferior lobe; previous lesions have grown in size (Figure 2).

Chest computed tomography (CT) scan performed 2 days later (Figure 3) revealed: 
- a pulmonary consolidation area of $8.6 / 4.8 \mathrm{~cm}$ with air bronchogram presence in the apical segment of the lower right lobe extended to the dorsal and posterior segments of upper right lobe;

- a similar image of $11.6 / 8.4 \mathrm{~cm}$ in the upper left lobe located in lateral, ventral and lingual segments;

- a third lesion in the left lower lobe of 7.9/9.6/7.6 cm in the apical and dorsal segments continuing with a $13.27 / 9.20 \mathrm{~cm}$ lung abscess image in the lower lobe located in ventral, dorsal and basal segments;

- multiple necrotizing lymphadenopathies in the anterior and superior mediastinum of $2.20 \mathrm{~cm}$ in diameter, in the right and inferior paratracheal areas of $3.40 \mathrm{~cm}$, in the

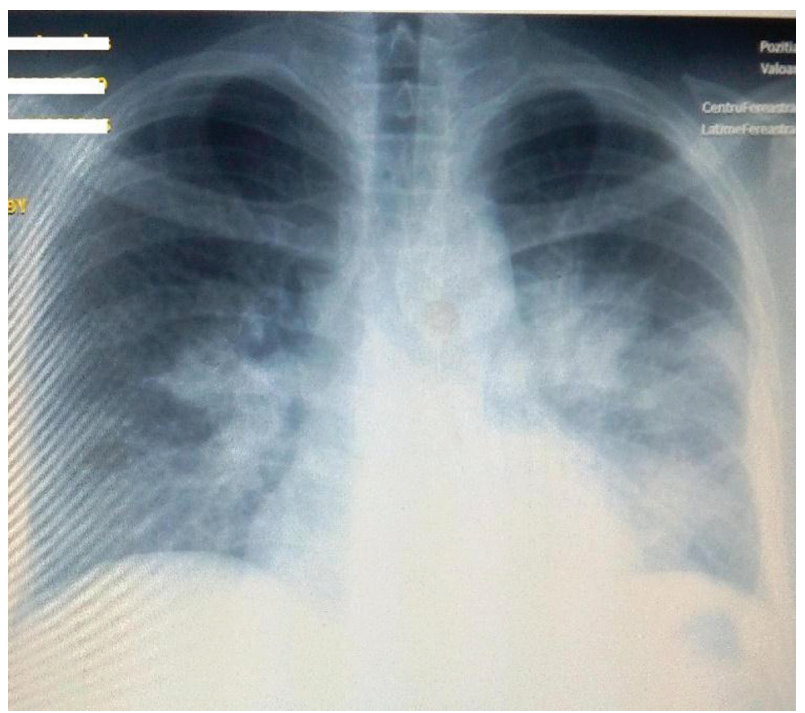

Figure 1. Initial chest X-ray: multiple diffuse opacities distributed in the half inferior part of both lung areas, suggestive of bilateral bronchopneumonia.
Barety's space of $3.4 \mathrm{~cm}$, in the aortopulmonary window of $4.10 \mathrm{~cm}$, in carinar and infracarinar spaces of about $4 \mathrm{~cm}$ and in both pulmonary hilums of 3.3 and $3.5 \mathrm{~cm}$ and - no evidence of pleural or pericardial effusion.

Acid fast bacilli (AFB) smear from sputum was positive and culture identified $M$. tuberculosis after 3 weeks. For our case, as for all cases of TB in PLH, we also used Xpert MTB/RIF for sputum examination. This test showed no resistance for $M$. tuberculosis. Using conventional culture and drug sensitivity testing for TB on Löwenstein-Jensen culture media, we confirmed no resistance after 2 months for $M$. tuberculosis.

He started specific first-line anti-TB treatment after diagnosis of pulmonary TB with isoniazid, rifampin, ethambutol and pyrazinamide in doses calculated for patient's weight, and he was monitored for adverse reactions.

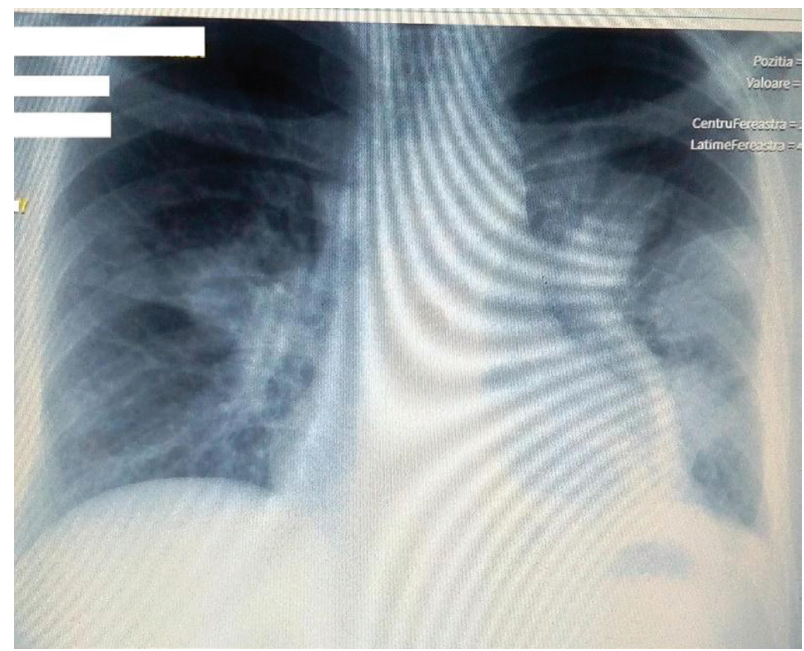

Figure 2. Chest X-ray after 7 days: a big oval cavity image of $13 \mathrm{~cm}$ in the left inferior lobe; previous lesions have grown.
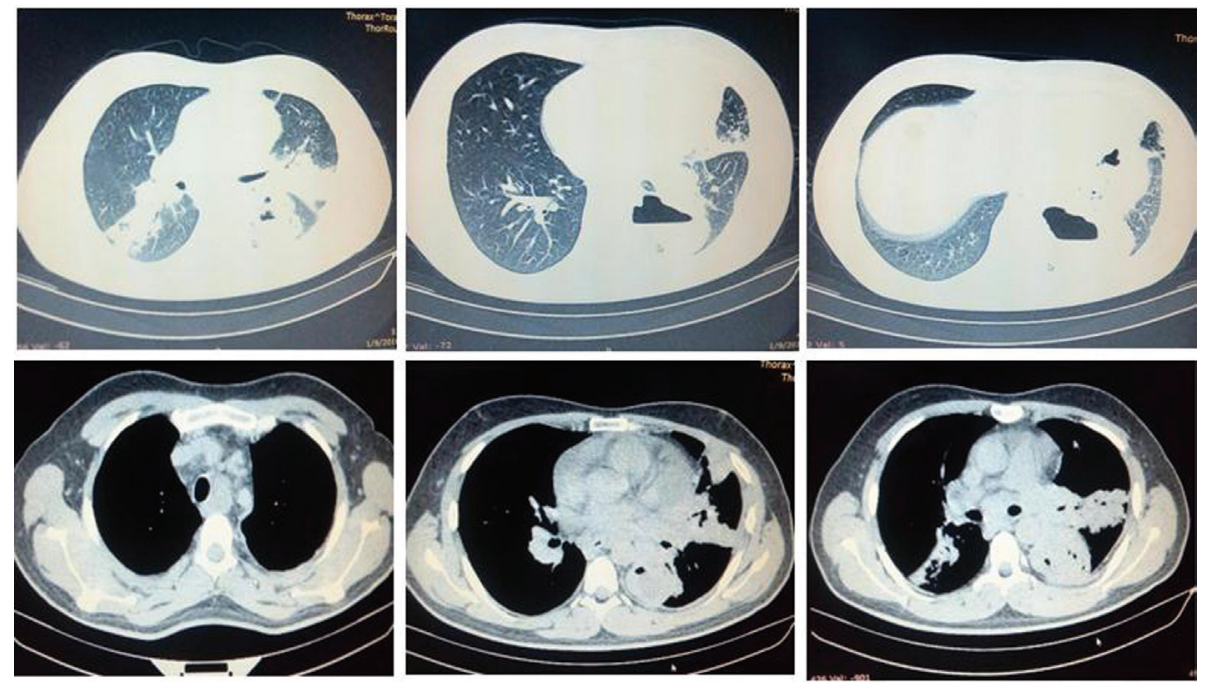

Figure 3. Multiple pulmonary consolidation areas located in left lung, and one consolidation area located in right lower lobe; multiple necrotizing lymphadenopathies in mediastinum. 
The patient was subsequently tested for HIV after his consent was taken. HIV testing is mandatory for all patients diagnosed with TB in Romania and requires patient's written consent in order to be tested. His test was positive, leading to the diagnosis of HIV infection category C3. The CD4 count was 189 cells $/ \mathrm{mm}^{3}$, RNA-HIV $(1,627,000$ copies $/ \mathrm{ml})$. Because the patient presented general pronounced weakness, he was also tested for hepatitis $\mathrm{B}$ and $\mathrm{C}$, and results were negative: $\mathrm{HbsAg}$ - negative and anti-HCV - negative.

Under specific anti-TB treatment, clinical evolution was favourable with the remission of fever and improved appetite. Also, he did not present any adverse effects, and radiological appearance improved after 2 months.

Antiretroviral treatment was initiated 3 weeks after anti-TB treatment. He started with tenofovir, emtriva and isentress that were well tolerated.

After 6 months of anti-TB treatment (including 5 months of antiretroviral treatment), CD4 count was $305 \mathrm{cells} / \mathrm{mm}^{3}$, RNAHIV $(60,200$ copies $/ \mathrm{ml})$. Due to his C3 stage of HIV infection and low number of $\mathrm{CD} 4$, the patient started also prophylactic treatment with co-trimoxazole.

After 12 months, the patient gained $15 \mathrm{~kg}$ and had no respiratory symptoms. In addition, his AFB smears and cultures for $M$. tuberculosis were negative. His chest X-ray improved but with the persistence of a small cavity, $2 \mathrm{~cm}$ in diameter, in the left lower lobe, which was associated with fibrosis in the left lower lobe and laterothoracic and supradiaphragmatic sequelae (Figure 4).

Anti-TB treatment was extended to 14 months. Antiretroviral treatment remained unchanged.

\section{Discussion}

HIV and M. tuberculosis amplify each other at cellular and molecular levels, where they disturb specific mechanisms of defence, leading to accelerated disease in PLH (8).

TB-HIV coinfection causes accelerated immune system damage with an increased mortality. Severe immunosuppression modifies and delays clinical, radiological and bacteriological expression of TB. Infection with HIV and M. tuberculosis has been dubbed as "the cursed duet" (9).

Our case had no previous medical history, and he denied having any contact with known HIV or TB cases. Symptoms for our case were atypical as a debut for TB, and the patient was misdiagnosed as having bronchopneumonia at first. Hence, AFB smears were obtained after unfavourable evolution (clinical and radiological) despite his antibiotic treatment. In addition, due to mandatory testing for HIV for all TB cases in Romania, our patient was also diagnosed with HIV infection stage C3.

His CD4 count of 189 cells/L was very low, and this explains the atypical radiological and clinical presentation. Rarely, for

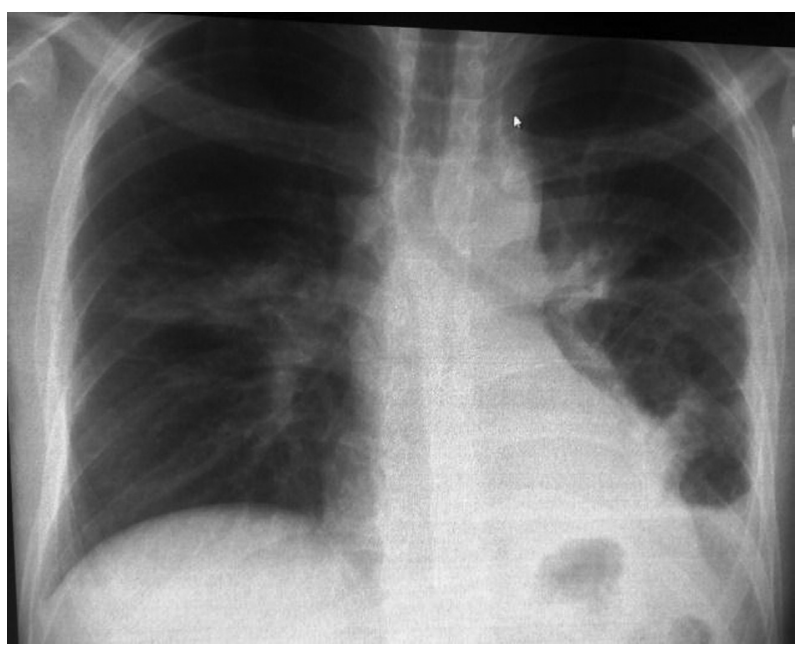

Figure 4. Chest X-ray after 12 months: a small cavity image of $2 \mathrm{~cm}$ in the left inferior lobe, laterothoracic and supradiaphragmatic sequelae.

such an immunocompromised patient, we also have positive AFB smears from sputum.

Atypical chest $\mathrm{X}$-ray findings are specific for altered immunity and for reactivation of primary TB sequelae in HIV-infected patients. As the CD4 count falls less than 200 cells $/ \mathrm{mm}^{3}$, PLH with pulmonary TB often have atypical chest X-ray, including pleural effusion, infiltrates nonspecific for TB located in lower or middle lobes and mediastinal lymph node enlargement or a normal chest X-ray $(10,11)$.

Enlarged lymph nodes can be linked to a lot of benign or malign diseases: reactive lymphadenitis, granulomatous lymphadenitis in tuberculous and nontuberculous infections, fungal lymphadenitis, Kaposi sarcoma, Hodgkin and non-Hodgkin lymphomas, primary tumours or metastasize. In addition, adenopathies are very common in AIDS patients, seen in all stages of HIV infection linked to the level of the immunosuppression $(12,13)$.

Our case presented pulmonary consolidation areas in both lung areas, a $13 \mathrm{~cm}$ left lung abscess and a lot of multiple necrotizing mediastinal lymphadenopathies. Considering the fact that our patient has severe immunosuppression and that his diagnosis of pulmonary TB was confirmed by isolating $M$. tuberculosis, we think that all his enlarged lymph nodes reflect an ineffective immune system response during HIV infections because of the reactivation of the previously acquired TB.

Sometimes the diagnosis of TB in HIV-infected patients may be delayed due to atypical clinical and radiological signs and low rates of positivity for sputum smear, and Gene Xpert (Xpert MTB/RIF) shall be used in HIV and AIDS patients to detect TB $(8,9)$. For our patient, TB was confirmed by culture and Gene Xpert testing.

According to Centers for Disease Control and Prevention (CDC) and European AIDS definition (14,15), a CD4 count of $<200 / L$ and coexistence of TB are AIDS criteria for a patient diagnosed with HIV infection. HIV progression to AIDS appears usually after years of HIV infection, but the rate of progression 
is very variable. CD4 lymphocyte count and viral load are most used for disease prognosis and monitoring PLH (16).

When both diseases need treatment in the same time, initiation of anti-TB treatment is a priority. The occurrence of side effects attributable to either anti-TB or antiretroviral treatment may compromise the initiation of TB treatment if both therapies are initiated simultaneously. If highly active antiretroviral therapy (HAART) is delayed, it may increase the risk of death due to HIV in severe immunocompromised patients. The optimal moment of introduction of HAART in patients receiving anti-TB treatment is ideally before 8 weeks since initiation of anti-TB treatment closely monitoring any adverse reaction (17). The choice of antiretroviral therapy (ART) should be based on efficacy and safety and should take into account potential drug-drug interactions between ART and rifamycins. Rifampin is a potent enzyme inducer that can accelerate drug metabolism, resulting in a significant reduction in antiretroviral drug efficacy. Rifabutin is an alternative to rifampin because it is a weaker CYP3A4 enzyme inducer, but it is not easily available for TB treatment in Romania, so TB regimen in our country includes rifampin (18). During HIV treatment, associated immune reconstitution inflammatory syndrome (IRIS) may occur. This is a clinical condition caused by specific antiretroviral treatment restoration of pathogen-specific immune responses to opportunistic infections. TB-associated IRIS (TB-IRIS) has been reported in $8 \%$ to more than $40 \%$ of patients starting HAART after TB is diagnosed, more often associated with low baseline CD4 count (50 cells/ $\mathrm{mm}^{3}$ ); high pre-HAART HIV viral loads; severity of TB disease, especially high pathogen burden and a less than 30-day interval between initiation of TB and HIV treatments. Most IRIS in HIV/TB disease occurs within 3 months of starting HAART (19). Despite his high viral count and high pathogen burden, our patient did not develop IRIS during his combined TB-HIV treatment.

Patients' adherence to treatment also plays a significant role in recovery. Diagnosis and treatment of TB in HIV-infected patients at an early stage of HIV infection is most effective.

Our clinical case showed that the cure of TB is also possible in severe immunosuppressed stages of HIV infection with the correct choice of treatment and close monitoring. In addition, every patient with HIV infection requires and receives professional psychological support with training and conversation. This support sometimes is extended also to patient's family.

\section{References}

1. Jaiswal RK, Srivastav $\mathrm{S}$, Mahajan $\mathrm{H}$. Socio demographic profile of TB-HIV co-infected patients in Bundelkhand Region, UttarPradesh. National Journal of Medical Research. 2012;2:149-151.

2. Corbett EL, Watt CJ, Walker N, Maher D, Williams BG, Raviglione MC, et al. The growing burden of tuberculosis: global trends and interactions with the HIV epidemic. Archives of Internal Medicine. 2003;163:1009-1021.
3. Lawn S, Churchyard G. Epidemiology of HIV associated tuberculosis. Current Opinion in HIV and AIDS. 2009;4:325-333.

4. World Health Organization. A Clinical Manual for Southeast Asia. WHO/TB/96.200(SEA).

5. Grecu VI, Călăraşu C, Olteanu M, Turcu AA, Riza A, Nitu FM. Profile of respiratory and extra-respiratory tuberculosis in patients living with HIV in Dolj County between 2005-2015. Current Health Sciences Journal. 2017; 43(3):220-225.

6. Man MA, Arghir OC, Man S, Streba CT, Olteanu M, Nitu M. Fatal paradoxical cryptic miliary tuberculosis and immune reconstitution disease in a young non-HIV immunocompromised male patient-case report with autopsy findings. Romanian Journal of Morphology and Embryology. 2014; 55(2): 453-457.

7. Nitu FM, Olteanu M, Streba CT, Jimborean G, Postolache P, Man MA, et al. Tuberculosis and its particularities in Romania and worldwide. Romanian Journal of Morphology and Embryology. 2017; 58(2): 385-392.

8. Kwan CK, Ernst JD. HIV and Tuberculosis: a deadly human syndemic. Clinical Microbiology Review. 2011; 24(6):351-376.

9. Zumla A, Malon P, Henderson J, Grange JM. Impact of HIV infection on tuberculosis. Postgraduate Medical Journal. 2000; 76:259-268.

10. Greenberg SD, Frager D, Suster B, Walker S, Stavropoulos C, Rothpearl A. Active pulmonary tuberculosis in patients with AIDS: spectrum of radiographic findings (including a normal appearance). Radiology. 1994; 193:115-119.

11. Keiper MD, Beumont M, Elshami A, Langlotz CP, Miller WT Jr. CD4 $\mathrm{T}$ lymphocyte count and the radiographic presentation of pulmonary tuberculosis. A study of the relationship between these factors in patients with human immunodeficiency virus infection. Chest. 1995; 107:74-80.

12. Navarro WH, Kaplan LD. AIDS-related lymphoproliferative disease. Blood. 2006;107(1):13-20.

13. Byzov AB. Lymphadenopathies in HIV. Available from: https://lib.ugent.be/fulltxt/RUG01/001/458/830/RUG01001458830_2011_0001_AC.pdf.

14. Centers for Disease Control (CDC). Update on acquired immune deficiency syndrome (AIDS) - United States. MMWR Morb Mortal Wkly Rep. 1982;31:507-508, 513-514.

15. Ancelle-Park R. Expanded European AIDS case definition. Lancet. 1993;341:441.

16. Mellors JW, Munoz A, Giorgi JV, Margolick JB, Tassoni CJ, Gupta P, et al. Plasma viral load and CD4+ lymphocytes as prognostic markers of HIV-1 infection. Annals of Internal Medicine. 1997;126:946-954.

17. Abdool Karim SS, Naidoo K, Grobler A, Padayatchi N, Baxter C, Gray A, Gengiah T, et al. Timing of initiation of antiretroviral drugs during tuberculosis therapy. The New England Journal of Medicine. 2010;362(8):697-706.

18. Abdool Karim SS1, Naidoo K, Grobler A, Padayatchi N, Baxter C, Gray AL, et al. Integration of antiretroviral therapy with tuberculosis treatment. N Engl J Med. 2011;365(16):1492-1501.

19. Michailidis C, Pozniak AL, Mandalia S, Basnayake S, Nelson MR, Gazzard BG. Clinical characteristics of IRIS syndrome in patients with HIV and tuberculosis. Antiviral Therapy. 2005;10(3):417-422. 